\title{
Case Role in the Urhobo Language
}

\author{
IMU, Oghoghophia Famous ${ }^{a, *}$
}

a National Institute for Nigerian Languages, ABA, School of Linguistics and Nigerian Languages, Nigeria.

*Corresponding author Email: Omufamous@gmail.com

DOI: https://doi.org/10.34256/ijll2113

Received: 23-03-2021, Accepted: 28-03-2021; Published: 30-03-2021

Abstract: This paper examines case role in the Urhobo language. Case theory is used as theoretical frame work, the specific objectives is to investigate type of cases and to relate cases roles to argument structures in Urhobo. The study reveals that in the Urhobo language every lexically headed NP must receive case from a case assigner. The Case theory requires that the case assigner govern the NP to which its assigns case. Tense, verb and preposition are case assigners. The infinitive 'to' and the passive participles are not case assigners. Case assignment can take place only when the case assigner and the NP to which it assigns case bear a structural relation to one another. It also reveals that irrespective of the theory and its arguments, Urhobo verbs are the basses and centre of its expansion of its constructions. This research also finds out, that the argument structures identified in universal grammar (UG) align with the argument structure of the Urhobo language; the verb assigns arguments to the noun phrases in a sentence. This is traced to the structure of the Urhobo language which is subject-verb-object (SVO). Finally, the study reveals that the function of the nominative case is to mark the subject of the sentence; the vocative is the case of address; the accusative is used to mark the object of a transitive verb; the genitive is the case of possession, ablative case is to mark the instrument with which something is done and the dative case marks the indirect object in the Urhobo language.

Keywords: Ablative, Accusative, Dative, Genitive, Nominative, and Vocative Case, Urhobo.

\section{Introduction}

\subsection{Background to the study}

The minimalist program has modified the assumption of the case assignment. This modification is the form of case checking. Minimalism does away with deep and surface structures entirely and retains only the logical and phonetic form levels. The proposal is that in the derivation process, features of the combining elements need to be checked. The checking is for two principal reasons: to ensure that the derivation is well formed at the phonetic level to be pronounceable, and account for the logical derivation of syntactic structures so that it can be meaningful (Mbah 2012). In other words, every un-interpretable feature is checked and every illogical construction is also prevented. An aspect of checking flows from spec-head relation. SPEC is a dummy node, which acts as a filter against elements being copied into or across it. For instance, it does not allow wh-elements to move into COMP positions already containing wh-heads. In other words, the wh-head adjusts to accommodate the element being copied into it, e.g

[Spec [comp Wh [s You saw whom] s] comp] spec?

\section{Literature review}

\subsection{Theoretical studies}

Case theory deals with the assigning of cases to noun phrases by the category that governs them. Anderson (1984) asserts that case as a category is an Anglicisation of the Latin 'Casus' which is a translation of the Greek word 'ptosis' meaning 'fall'. Case traditionally represents the forms of nouns (including true nouns or 
substantive, and other case-marked classes, such as adjectives). Nouns may be classified, or declined depending on their ptoseis (plural). Lyons (1968) sees case as the most important inflexional category of the verb. It is significant that the term "case" (originally more or less synonymous with what was later called inflexion) was restricted to one particular inflexional category. The reason for this would seem to be that most of the other categories-gender, number, tense, person etc could be related to a principle of semantic classification.

Fillmore (1968) says that "a verb can have one, two or three nouns (or noun phrases) associated with it, corresponding generally to the intransitive, normal transitive, and transitive indirect object sentence types respectively. In a three noun sentence, continues Fillmore (1968), the case of the nouns are nominative which is the case of the agent, the accusative, the case of the patient and the dative, 'the residual' case which is capable of expressing any notion compatible with the meaning of the third noun in the sentence. He goes on to conclude that in two noun sentences, one of the nouns is nominative and the other either dative or accusative but typically accusative.

Case theory is used for a variety of functions including marking the instrument with which something is done e.g.

\section{1). The rock broke the window}

In sentence (1) above, the rock is the subject and has the theta role of instrument.

The insertion of verb according to Fillmore (1968) depends on the particular array of case, the case frame provided by the sentence. The verb 'run' for example may be inserted into the frame (A) Agentive, the verb 'sad' into the frame (D) Dative, a verb like remove and 'open' into $(O+A)$ Objective plus Agentive, verbs like 'murder' and 'terrorise' (that is, verbs requiring animate subject) into ( $D+A)$ Dative plus Agentive, verb like give into $(O+D+A)$ Objective plus Dative plus Agentive. Dative is the case of the animate being affected by the state, or action identified by the verb, Objective is the semantically most neutral case of anything representable by a noun whose role in the action or state identified by the semantic interpretation of the verb itself... while agentive, the case of the typically animate perceived instigator of the action identified by the verb.

Fillmore's work has shown an interest in lexical semantics. And the effort in case grammar has been devoted to show that the sub-categorisation and lexical relations are sensitive to case relations rather than the configurations and grammatical relations that are derivable in case grammar. (see Fillmore 1968, 1977, Imu 2015, 2019).

Chomsky (1981) asserts that case assignment is closely related to government. Case is assigned to an NP by a category that governs it. As for the notion 'government', the potential governors are the categories $(\mathrm{N}, \mathrm{V})$ and (INFL), that a category governs its complement in a construction of which it is the head. E.g. (V governs VP) and that (INFL) governs the sentence subject when it is tensed e.g TABLE]]]].

2) John (INFL[+ tense]] [VP [v think] [S he [INFL [+ tense]] [VP leave [NP his book] [PP[P ON] [NP THE

John thought that he left his book on the table.

The matrix verb 'think' governs its complement $S$ 'that he left'. The embedded verb 'leave' governs it complement 'his book' and 'on the table', but does not govern any element (e.g his or the table) within the categories. Thus, 'his book' and 'book' receive objective case. The two occurrences of INFL govern John and he, assigning them nominative case. The preposition 'on' governs and assigns oblique case to the complement 'the table'. The genitive rule assigns genitive case to the ungoverned element his (Chomsky, 1981).

Rienskijik and Wiliams (1986) observe that 'every lexically headed NP must receive case from a case assigner". The Case theory requires that the case assigner governs the NP to which it assigns case. Tense, verb and preposition are case assigners. The infinitive 'to' and the passive participles are not case assigner. Case assignment can take place only when the case assigner and the NP to which it assigns case bear a structural relation to one another, the relation is known as government. If case is assigned under government, and if every lexical NP must appear in a position in which it is governed by some case assigners, then, in general, a lexical NP 
cannot appear as the subject of a non-tensed sentence. Non-tense or [-tense] is shown in a sentence by the infinitival 'to' e.g.

(3) The student prefer for Bill to visit Paris.

In this sentence, the complementiser 'for' infinitive 'to' are [-te3nse] (see Chomsky 1981). Therefore, case assignment relates to grammatical functions such that a number of semantic roles may be associated with the same grammatical function. Below are case environment:

$\begin{array}{ll}\text { Environment } & \text { case } \\ (\mathrm{V}-) & \text { accusative } \\ \text { [-tensed VP] } & \text { nominative } \\ \text { [-NP] } & \text { accusative }\end{array}$

(See Riensdijk and Williams (1986).

Napoli (1996) equally points out that agreement [AGR] is a case assigner: "[+AGR] is a case assigner; [AGR] is not, and the subject gets its case from [+AGR]". The following are the case assigners identified in course of this research: Tense, Verb, Preposition and Agreement

\subsection{Theoretical framework}

The theoretical framework adopted for this work is Case theory. It deals with the assigning of cases to noun phrases by the category that governs them

\subsection{Empirical studies}

Aziza (2010) examines transitive and intransitive verbs. The transitive verb obligatorily take objects while the intransitive verbs do not take an object, and that transitive verbs may be used intransitively, when that happens, the construction takes an -rv suffix, with varying realisations, depending on the ATR requirements and some morphophonemic rules of the language.

Ajiboyi (2014) looks at the description of some of the morphological factors involved in compounding in Urhobo. It was observed that Urhobo has both headed and headless compounds. Though the heads of Urhobo compounds are left branching, there are instances where the heads are right branching. Pronominal affixes were found to head some Urhobo compounds.

Aziza \& Utulu (2018) did a comparative study of Ėwùlù and Ùrhòbò and explored the various procedures by which both languages adopt in deriving compounds. The study adopts a descriptive approach, that Èwùlù and Ùrhòbò, though are two different Nigerian languages, yet exploited almost the same morphological patterns of compounding to create new words.

\subsection{Summary of literature}

The review above shows that case theory is used for a variety of functions including marking the instrument with which something is done. The study shows that a lot has been done in other languages, little or none has been done in the Urhobo language hence this work.

\section{Case in the Urhobo language}

Case deals with the assigning of cases to noun phrases by the category that governs them. Case traditionally represents the forms of nouns (including true nouns or substantives, and other case-marked classes, such as adjectives). The following are the number of cases identified in the Urhobo language. 


\subsection{Nominative Case}

This is the case that marks the subject. Napoli (1996) asserts that the nominative case is generally used for subjects Riemsdijk and Williams (1986) postulate that the nominative case is assigned to an NP that is governed by an INFL (ection) node that is headed by (+Tns) tense e.g

(4a) ẹ̀sè̀ rẹ̀ èmù èvùrẹ̀ idjèrè

name eat food inside road

Ese ate food on the road

b) Òkòrò gbè èrhà

name dance pst dance

Òkòrò danced

c) ọ̀mọ̀ rẹ̀ èmù nà

name eat pst food that

ọmọ̀ ate the food

In the sentence above, èsè̀, Ókòrò and ọmọ are the grammatical subject and performs the theta roles of the agent

\subsection{Accusative case}

The accusative case is used to mark the object of a transitive verb. Comrie (1989) remarks that the accusative case is for the direct object or in frameworks that eschew the distinction between syntactic and semantic cases, the accusative correlates with patient. The accusative case is use to mark the direct object or in frameworks that eschew the distinction between syntactic and semantic cases, the accusative correlates with patient. e.g

5a) Titi rè̀ èmù nà èvùrẹ̀ ùwẹ̀vwi mẹ name eat pst that inside house my

Titi ate the food in my house

b) Atàirè mùè òchẹ nà kpẹ̀ ùrhiè Name carry clay pot go pst river Atàirè took the clay pot to the river

c). okẹ̀ mwmà ibiẹ̀di nà name pound pst palm nut that okẹ pounded the palm nut

Here the mùè, òchẹ and ibiẹdi are the grammatical objects of the sentences and perform the theta roles of patient. The accusative case is used to mark the object of a transitive verb in the Urhobo Language

\subsection{Dative case}

This case marks the indirect object in a sentence e.g.

6a) mè vwẹ òchẹ nà vwò kẹ̀ ònimẹ̀ I use clay pot that to give pst mother my

I gave the clay pot to my mother 
b) okẹ̀ siẹ obe kẹ̀ osẹ̀rẹ̀yẹ name write book give pst father his okè wrote a letter for his father

c) òkòrò dùẹ̀ ayè osẹ̀rè̀yè name sex pst wife father his òkòrò slept with his father's wife

In sentences, 6a-c, ònimè, osẹrrèyè and osẹrrèyè are the grammatical indirect objects of the sentences and have the theta roles of the recipient.

\subsection{Genitive case}

This case is used to mark what Lyons (1968) calls adnominal possessive. Genitive is used to show possession e.g.

(7a). ọ̀nànà ùwèvwi rẹ̀ osẹ̀mẹ

That that house of father my

This is my father's house

b) ùwèvwi nà ọ̀ mẹ

House that my

The house is mine

c) ọ̀nànà ayè rẹ̀ osẹ̀rẹ̀yè

that that wife of father his

this is his father's wife

These sentences show the grammatical functions of possession and it has no clear theta roles

\subsection{Vocative case}

Vocative case is the case that is used for address e.g.

(8a. ộọ̣kộ dià òrèrè rẹ̀ òyibò

name live town of white man

ọ̀kọkộ lives in London

(b) òyònò mè̀ dià òrhò rẹ̀ Nsukka

Lecturer my live town of Nsukka

My lecturer lives in Nsukka town

c). Ònimẹ̀ nẹ̀ orèrè rẹ̀ Òkpẹ̀ rhẹ

Mother my from town of name from

My mother came from Òkpè

Here, the sentences show the grammatical functions of address, it identifies where the entities lives, came from and have the theta roles of location. 


\subsection{Ablative case}

This ablative case is used for a variety of functions including marking the instrument with which something is done e.g.

(9a). Òdà nà brò òbò mẹ

Machete that cut hand my

The machete cut my hand

(b) $\quad 0$ vwẹ̀ urhẹ̀ na bẹ̀rẹ̀ uyovwi ẹ̀wẹ̀ nà

$\mathrm{He} / \mathrm{she}$ use wood that break head goat that

He use the wood to break the goat's head

c). imòtòsò nà bẹè ùrhè̀ nà

motor saw that splint food that

The motor saw splinted the food

In sentences (9a-c) above, the machete, motor saw and the wood are the subjects and- have the theta roles of instruments..

\section{Summary of findings and conclusion}

The study reveals that every lexically headed NP must receive case from a case assigner. The Case theory requires that the case assigner govern the NP to which it assigns case. Tense, verb and preposition are case assigners.

The infinitive 'to' and the passive participles are not case assigners. Case assignment can take place only when the case assigner and the NP to which it assigns case bear a structural relation to one another, the relation is known as government.

It equally reveals that irrespective of the theory and its arguments Urhobo verbs is the basses and centre of its expansion of its constructions.

In the Urhobo language, the verb brings out the actions in a given sentence(s). For instance, the verb 'hwe' (kill) in Urhobo suggests that an entity loses life as a result of the activities of another entity, the verb is a link in any argument structure; it gives the meanings of the sentences under consideration, the relationship between the verb and its arguments is a mutual one. Moreover, verbs assign argument to the nouns and the complements. Therefore, verb argument structure operates effectively in the traditional classification, theta function and the case roles in the Urhobo Language.

In this research, we discovered that the argument structures identified in universal grammar (UG) align with the argument structure of the Urhobo language. The verb assigns arguments to the noun phrases in a sentence. This is traced to the structure of the Urhobo language which is subject-verb-object (SVO), This is similar to the structure of the majority of the world's languages taking into consideration, the theory that the verb "give" (ke) takes three argument structures as in 'give' $(a, b, c$,$) is perfectly so in the Urhobo language. It should also$ be noted that the copula verbs that are of one argument structure in other languages are also the same in Urhobo language.

\section{References}

E.M. Ajiboye (2014). Compounding in Urhobo. Journal of West African Languages, 41(1) 13-29.

Anderson, J.M. (1984). Case grammar and the localist hypothesis. In Driven \& Radden (Eds.), Concept of case. Tubingen: Gunter Narr. 
Aziza, R.O., (2010). Urhobo syntax. In Y, Ọre, (Ed.), Basic linguistics for Nigerian languages, (pp. 305-326). Port Harcourt: LAN.

Aziza, R.O., Utulu, D.C., (2018). Compounding in Urhobo and Ewulu. International Journal of Research in Humanities and Social Studies, 5(3) 24-30.

Chomsky, (1981). Lectures note government and binding. Foris, Dordrecht.

Comre, B., (1989). Language universal and linguistic typology. Blackwell, Oxford.

Fillmore, C.J., (1968). The case for case. In E. Bach and R. T. Harms (Eds), Universals in linguistic theory.1-88. Holt, Richard and Winston, New York.

Fillmore, C.J., (1977). The case for case reopened. In R. W. Cole (Ed). Current issues in linguistic theory, Indiana University Press, Bloomington.

Imu, F. O., (2015). Argument structure of the Urhobo verbs: A minimalist application. M. A dissertation, University of Nigeria.

Imu, F.O., (2019). Morphosyntactic analysis of verb compounding in Urhobo. Ph.D dissertation, University of Nigeria.

Lyons, J., (1968). Introduction to theoretical linguistics. Cambridge University, London.

Mbah, B. M., (2012). GB syntax: a minimalist theory and application to Igbo. Catholic Institution for Development Justice and Peace Press, Enugu.

Napoli, D.J., (1996). Linguistics. Oxford University Press, Oxford.

Riemsdijk, H.V., \& William, E., (1986). Introduction to the theory of grammar. MIT Press, London.

\section{Funding}

No funding was received for conducting this study.

\section{Conflict of interest}

The Author has no conflicts of interest to declare that they are relevant to the content of this article.

\section{About the License}

(C) The author 2021. The text of this article is open access and licensed under a Creative Commons Attribution 4.0 International License 